\title{
Chitotriosidase Activity in Goat Blood and Colostrum
}

\author{
A. Argüello, ${ }^{* 1}$ N. Castro, ${ }^{*}$ M. Batista, ${ }^{*}$ I. Moreno-Indias, ${ }^{*}$ A. Morales-delaNuez, ${ }^{\star}$ D. Sanchez-Macias, ${ }^{*}$ \\ E. Quesada, ${ }^{*}$ and J. Capote† \\ *Department of Animal Science, Las Palmas de Gran Canaria University, Arucas 35416, Spain \\ †Canary Agronomic Science Institute, La Laguna, Tenerife 38200, Spain
}

\begin{abstract}
Chitotriosidase (ChT) activity has not been investigated in ruminants, and therefore, we studied this activity in blood and colostrum of 25 pregnant goats and 60 goat kids. Blood samples were taken from pregnant goats at 3,2 , and $1 \mathrm{~d}$ prepartum; at partum; and at 1, 2, 3, and $4 \mathrm{~d}$ postpartum. Colostrum samples were obtained by machine-milking at partum and 1, 2, 3, and $4 \mathrm{~d}$ postpartum. Goat kid blood was collected at birth and every $7 \mathrm{~d}$ thereafter until goats kids were 56 $\mathrm{d}$ old. The ChT activity ranged from 2,368 to $3,350 \mathrm{nmol} /$ $\mathrm{mL}$ per hour in goat blood serum, and no statistical differences were detected through time. However, activity tended to decrease from $3 \mathrm{~d}$ prepartum to $2 \mathrm{~d}$ postpartum. Colostrum ChT activity was $3,912 \mathrm{nmol} / \mathrm{mL}$ per hour and $465 \mathrm{nmol} / \mathrm{mL}$ per hour on the day of delivery and $4 \mathrm{~d}$ postpartum, respectively. Colostrum ChT activity was significantly higher at partum than at any other time. The ChT activity in colostrum was significantly greater at $1 \mathrm{~d}$ postpartum than at 2,3 , and $4 \mathrm{~d}$ postpartum. Chitotriosidase activity did not differ in colostrum collected on d 2, 3, and 4 postpartum. Chitotriosidase activity in goat kid blood serum ranged from 2,664 to $9,231 \mathrm{nmol} / \mathrm{mL}$ per hour at birth and $49 \mathrm{~d}$ of life, respectively. Chitotriosidase activity in the blood serum increased with age: at birth, activity was significantly less than at $28,35,42,49$, and $56 \mathrm{~d}$ postpartum. The maximum ChT activity in blood serum was observed at $49 \mathrm{~d}$ postpartum. Activity in 49-d-old kids was significantly greater than that observed in kids at 0,7 , and $14 \mathrm{~d}$ postpartum.
\end{abstract}

Key words: chitotriosidase, goat, blood, colostrum, goat kid

\section{INTRODUCTION}

The primary function of mammalian milk is to provide nourishment, but colostrum also serves to trans-

Received November 3, 2007.

Accepted January 17, 2008.

${ }^{1}$ Corresponding author: aarguello@dpat.ulpgc.es port molecules related to immune and intestinal function from mother to newborn (Hennart et al., 1991; Ellis et al., 1996). A wide array of biologically active compounds (e.g., hormones, cytokines, and enzymes) present in milk, and particularly in colostrum, control proliferation, survival, differentiation, and function of the neonatal intestine (Hirai et al., 2002). The high IgA concentration in human colostrum (Araújo et al., 2005) protects gut mucosa. Immunoglobulin $\mathrm{G}$ is the major Ig in ruminant colostrum (Argüello et al., 2006). Thus, colostrum may play a role in local defense against microorganisms.

Chitotriosidase (ChT) is a functional chitinase with high homology to chitinases that belong to family 18 of glycosylhydrolases that are present in different species (Barone et al., 1999). This enzyme is predominantly a secretory protein, but it is also processed and stored to lysosomes. In cell culture, ChT mRNA is only expressed at the late stage of monocyte differentiation, indicating that expression of this enzyme is strongly regulated. Chitotriosidase is able to hydrolyze chitin in the cell wall of fungi and nematodes. Thus, it is possible that this enzyme plays a role in defending against parasites and fungi (Renkema et al., 1998). There are many studies of human ChT but few of other mammalian endocrine chitinases. The one exception is a study by Suzuki et al. (2001), in which they identified and purified a new serum chitinase in bovine liver. The aim of the current study was to measure ChT activity in goat blood serum and colostrum in the early postpartum days, as well as in the blood of goat offspring.

\section{MATERIALS AND METHODS}

Twenty-five pregnant Majorera goats (4 yr old) were used in this study. All animals were clinically healthy during the experimental period. The animals were fed corn, soy 66, dehydrated lucerne, dehydrated beetroot, wheat straw, and a vitamin-mineral corrector in accordance with the guidelines issued by L'Institut de Recherche Agronomique (Jarrige, 1990). Composition of the ration based on DM (\%) was $6.2 \%$ ash, $10.6 \% \mathrm{CP}$, $10.2 \%$ crude fiber, and $2 \%$ ether extract. Blood samples 


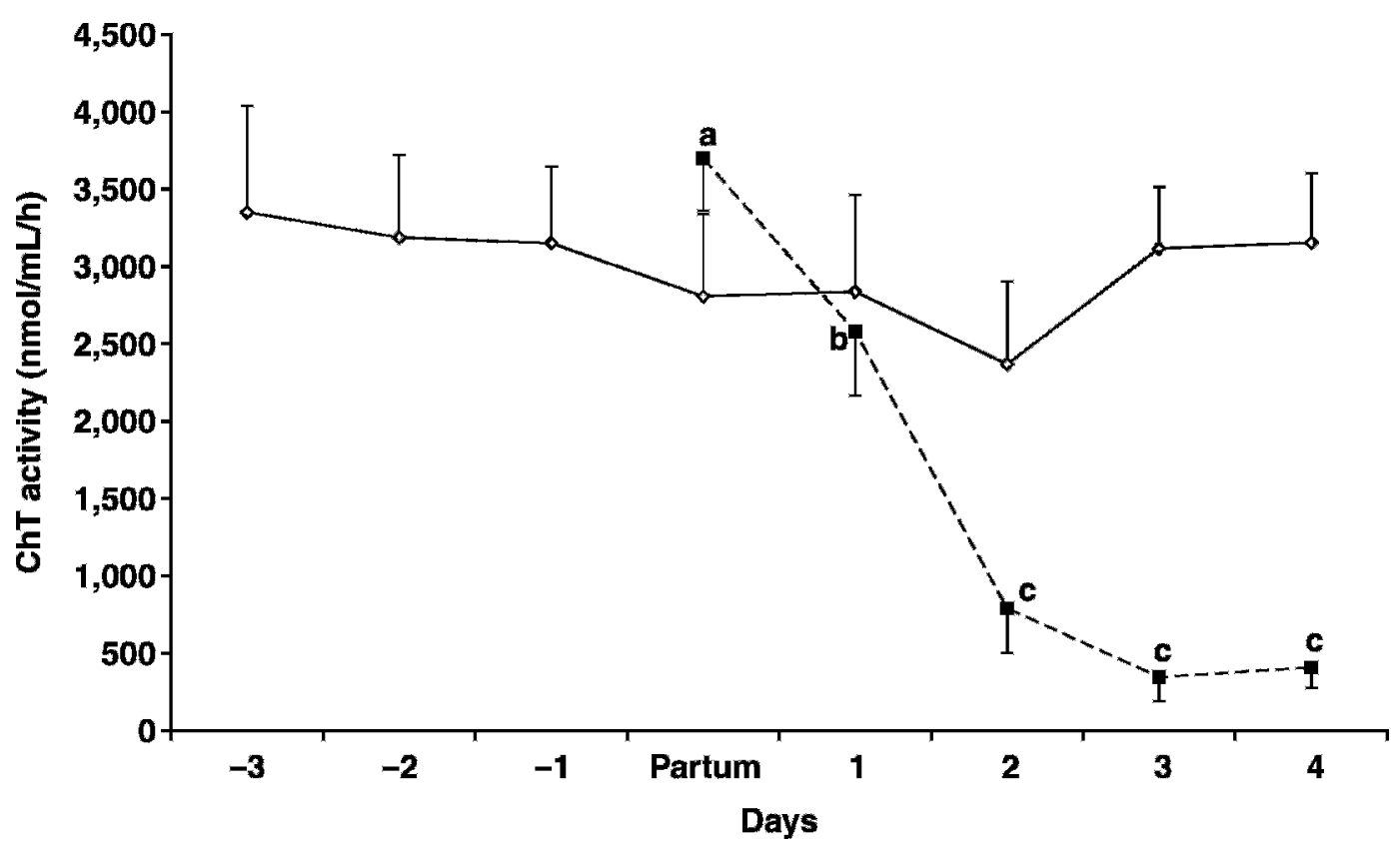

Figure 1. Chitotriosidase $(\mathrm{ChT})$ activity in blood serum $(\diamond)$ and colostrum $(\square)$ from adult female goats. Points labeled with different letters differ significantly $(P<0.05)$.

were collected daily from each animal at the same time, $4 \mathrm{~d}$ before delivery until $4 \mathrm{~d}$ postpartum. Colostrum samples $(50 \mathrm{~mL})$ were collected from foremilk at partum and daily thereafter until $4 \mathrm{~d}$ postpartum. The kids were separated from their mothers at partum, and goats were milked once a day throughout the experiment.

A previously collected fresh goat colostrum pool was used to feed the goat kids in this experiment. The animals were dried, and their umbilical cords were disinfected before they were weighed and identified. Animals were bottle-fed colostrum twice on the first day ( 2 and $14 \mathrm{~h}$ postpartum). Each feed contained 2,000 mg of IgG/ $\mathrm{kg}$ of BW in accordance with the management system proposed by Castro et al. (2005). Thus, the total IgG received was 4,000 $\mathrm{mg}$ of IgG/kg of BW. Subsequently, kids were fed milk replacer (Bacilactol Cabritos, Saprogal, La Coruna, Spain; 95.5\% DM, 23.6\% CP, and 22.7\% ether extract) as described by Argüello et al. (2004). Blood samples were collected at birth and every $7 \mathrm{~d}$ thereafter until $56 \mathrm{~d}$ of life.

The ChT activity was measured by incubating $1 \mu \mathrm{L}$ of undiluted blood serum with $100 \mu \mathrm{L}$ of a solution containing $22 \mathrm{mM}$ of an artificial substrate (4-methylumbelliferyl- $d-N, N^{\prime}, N^{\prime \prime}$ triacetylchitotriose) in $0.5 \mathrm{M}$ citrate phosphate buffer, $\mathrm{pH} 5.2$, for $15 \mathrm{~min}$ at $37^{\circ} \mathrm{C}$. The reaction was stopped with $5 \mathrm{~mL}$ of $0.5 \mathrm{M} \mathrm{Na}_{2} \mathrm{CO}_{3}$ $\mathrm{NaHCO}_{3}$ buffer, $\mathrm{pH}$ 10.7. Fluorescence was measured with a fluorimeter (Perkin Elmer, Norwalk, CT) at 365 $\mathrm{nm}$ of excitation and $450 \mathrm{~nm}$ of emission. The $\mathrm{ChT}$ activity is expressed as nanomoles of substrate hydrolyzed per milliliter per hour.

An ANOVA procedure was performed using SPSS (version 13.0, SPSS Inc., Chicago, IL) to evaluate the effect of time around partum in goats and age in kids. A Pearson correlation between ChT activity in goat serum and goat colostrum was measured.

\section{RESULTS AND DISCUSSION}

Figure 1 shows the progression of ChT activity in goat blood serum from $3 \mathrm{~d}$ prepartum to $4 \mathrm{~d}$ postpartum. The ChT activity ranged from 3,350 to $2,368 \mathrm{nmol} / \mathrm{mL}$ per hour in goat blood serum. Time around partum did not affect ChT activity, but a slightly downward trend was observed between $3 \mathrm{~d}$ prepartum and $2 \mathrm{~d}$ postpartum. Goat ChT activity was much higher than human ChT activity (Musumeci et al., 2005), which was found to range from $102 \mathrm{nmol} / \mathrm{mL}$ per hour in African women to $46 \mathrm{nmol} / \mathrm{mL}$ per hour in Caucasian women. These results suggest that $\mathrm{ChT}$ is more critical for goat immunity, perhaps due to the high preponderance of parasitic diseases in goats relative to humans.

Colostrum ChT activity ranged from 3,912 at partum to $465 \mathrm{nmol} / \mathrm{mL}$ per hour at $4 \mathrm{~d}$ postpartum. Colostrum ChT activity was significantly greater at partum than postpartum. Similarly, activity $1 \mathrm{~d}$ postpartum was less than at partum but significantly greater than 2,3 , and 


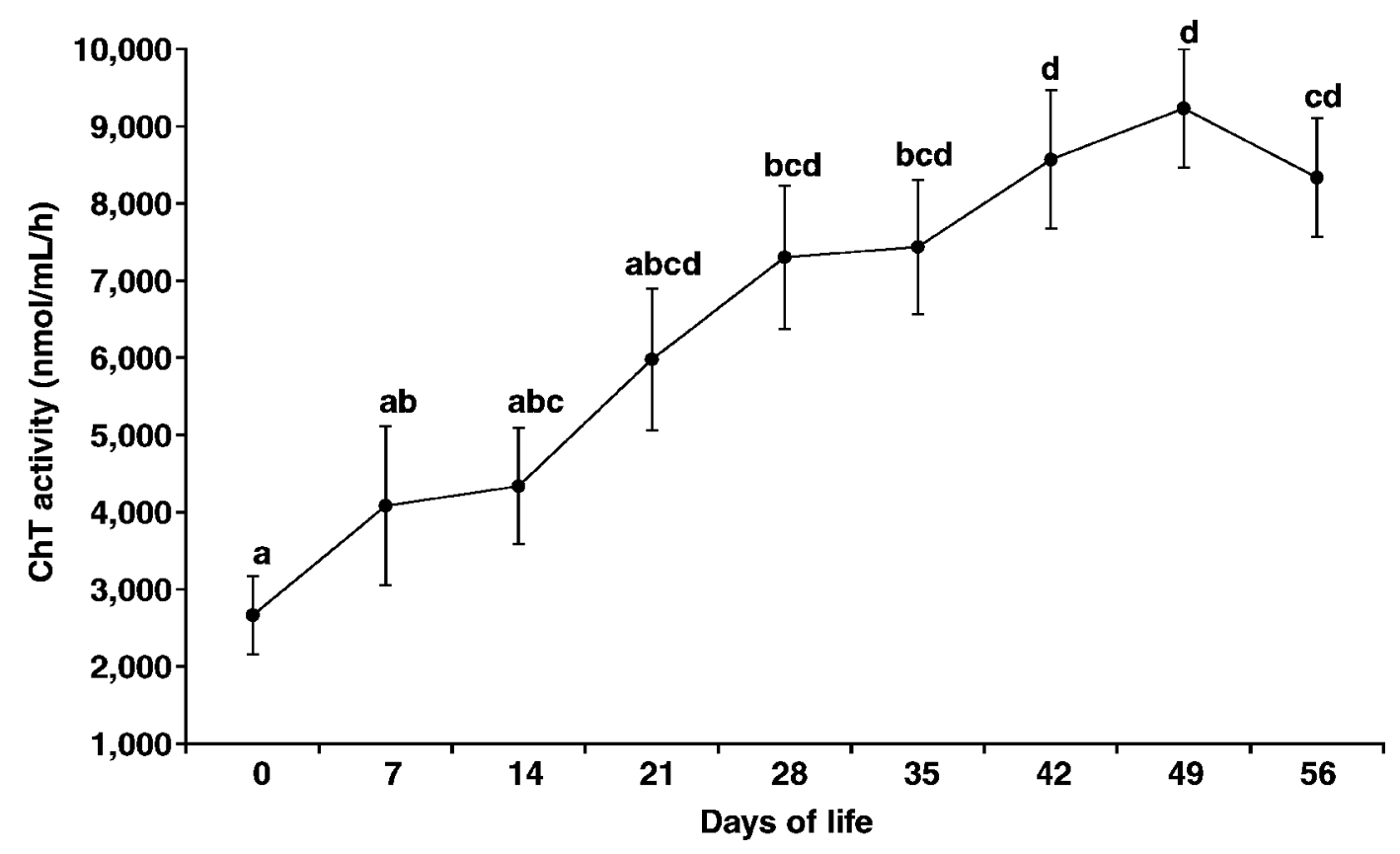

Figure 2. Chitotriosidase (ChT) activity in goat kid blood serum. Different letters denote statistical differences $(P<0.05)$.

4 d postpartum. Colostrum ChT activity did not differ significantly 2,3 , and $4 \mathrm{~d}$ postpartum. A decrease in colostrum ChT activity with postpartum day was reported in humans by Musumeci et al. (2005), but ChT activity in human colostrum $(1,230$ and $293 \mathrm{nmol} / \mathrm{mL}$ per hour in African and Caucasian women, respectively) was lower than in goat. Similar to humans (Musumeci et al., 2005), goat blood serum ChT activity and colostrum ChT activity were not correlated. Goat colostrum $\mathrm{ChT}$ was greater than human, indicating that $\mathrm{ChT}$ plays more of a protective role in goats than in humans. Goats are exposed to more parasitic and fungal infections than humans, which may explain the differences in ChT activity in these 2 species.

The ChT activity in goat kid blood serum ranged from $2,664 \mathrm{nmol} / \mathrm{mL}$ per hour at birth to $9,231 \mathrm{nmol} / \mathrm{mL}$ per hour at $49 \mathrm{~d}$ of life. Figure 2 shows that serum ChT activity increased with age. Blood serum ChT activity at birth was significantly less than at $28,35,42,49$, and $56 \mathrm{~d}$ postpartum. Serum ChT activity was maximal at $49 \mathrm{~d}$ postpartum and was significantly greater than that that measured at birth and 7 and $14 \mathrm{~d}$ postpartum, suggesting that ChT is not absorbed from colostrum. It has been proposed that goat kid macrophages are progressively activated with age. If $\mathrm{ChT}$ is not absorbed by goat kids, the primary role of colostrum ChT must be to protect the intestinal lumen. As is the case for many other proteins in breast milk, ChT may be inactivated or destroyed before arriving in the intestine (Wold and Adlerberth, 2000). However, a high concentration of ChT in colostrum may offer protection against pathogens. In keeping with this hypothesis, the prevalence of oral candidiasis in the first month of life is less in African babies than in Caucasian babies (S. Musumeci, unpublished data).

Colostrum and plasma ChT activity are not correlated in African or Caucasian women (Musumeci et al., 2005). Musumeci et al. (2005) suggested that high ChT activity in human colostrum is a consequence of local ChT secretion by activated macrophages. In contrast, we propose that ChT is transported from blood to colostrum in a manner similar to that of IgG. Chitotriosidase activity is much greater in the serum of goat kids than in adult goats that have recently given birth, suggesting that ChT is being transported from blood to colostrum in postpartum females. The ChT activity in adult goats and other ruminants requires investigation throughout the lactation period, and ChT in mammary tissue must be examined.

\section{CONCLUSIONS}

In conclusion, $\mathrm{ChT}$ is an important component of innate immunity against chitin-containing pathogens. Chitotriosidase activity is greater in goats than in humans, suggesting that ChT activity should be investigated in ruminants (cow, sheep, and buffalo) to clarify its mechanism of action. 


\section{REFERENCES}

Araújo, E. D., S. B. Carbonare, M. C. de Araújo, P. Palmeira, J. A. Amaral, and V. S. Sales. 2005. Total and specific IgA in colostrum and milk of mothers of Natal-Rio Grande do Norte. Bras. Acta Cir. Bras. 20:178-184.

Argüello, A., N. Castro, S. Alvarez, and J. Capote. 2006. Effects of the number of lactations and litter size on chemical composition and physical characteristics of goat colostrum. Small Rumin. Res. 64:53-59.

Argüello, A., N. Castro, and J. Capote. 2004. Growth of milk replacer kids fed under three different managements. J. Appl. Anim. Res. 25:37-40.

Barone, R., F. Di Gregorio, M. A. Romeo, G. Schiliro, and L. Pavone. 1999. Plasma chitotriosidase activity in patients with betathalassemia. Blood Cells Mol. Dis. 21:1-8.

Castro, N., J. Capote, S. Alvarez, and A. Argúello. 2005. Effects of lyophilized colostrum and different colostrum feeding regimens on passive transfer of immunoglobulin G in Majorera goat kids. J. Dairy Sci. 88:3650-3654.

Ellis, L. A., A. M. Mastro, and M. F. Picciano. 1996. Milk-borne prolactin and neonatal development. J. Mammary Gland Biol. Neoplasia 1:259-269.

Hennart, P. F., D. J. Brasseur, J. B. Delogne-Desnoeck, M. M. Dramaix, and C. E. Robyn. 1991. Lysozyme, lactoferrin, and secretory immunoglobulin A content in breast milk: Influence of duration of lactation, nutrition status, prolactin status, and parity of mother. Am. J. Clin. Nutr. 53:32-39.

Hirai, C., H. Ichiba, M. Saito, H. Shintaku, T. Yamano, and S. Kusuda 2002. Trophic effect of multiple growth factors in amniotic fluid or human milk on cultured human fetal small intestinal cells. J. Pediatr. Gastroenterol. Nutr. 34:524-528.

Jarrige, J. 1990. Alimentación de bovinos, ovinos y caprinos. Mundi Prensa, Madrid, Spain.

Musumeci, M., L. Malaguarnera, J. Simpore, R. Barone, M. Whalen, and S. Musumeci. 2005. Chitotriosidase activity in colostrum from African and Caucasian women. Clin. Chem. Lab. Med. 43:198201.

Renkema, G. H., R. G. Boot, F. Au, W. E. Danker-Koopman, A. Strijland, A. O. Muijsers, M. Hrebicek, and J. M. Aerts. 1998. Chitotriosidase, a chitinase, and the $39 \mathrm{kDa}$ human cartilage glycoprotein, a chitin-binding lectin, are homologues of family 18 glycosyl hydrolases secreted by human macrophages. Eur. J. Biochem. 251:504-509.

Suzuki, M., M. Morimatsua, T. Yamashitab, T. Iwanagac, and B. Syutoa. 2001. A novel serum chitinase that is expressed in bovine liver. FEBS Lett. 506:127-130.

Wold, A. E., and I. Adlerberth. 2000. Breast feeding and the intestinal microflora of the infant-Implications for protection against infectious diseases. Adv. Exp. Med. Biol. 478:77-93. 